\title{
Introduction: Historical Trajectories of Education and Development in (Post)Colonial Africa
}

\author{
Damiano Matasci, Miguel Bandeira Jerónimo \\ and Hugo Gonçalves Dores
}

"Among the many problems of Africa there is none that has attracted more discussion, and indeed more controversy, than that of the type of education which should be given to the African." Thus stated William Malcolm Hailey in his famous report An African Survey: A Study of Problems Arising in Africa South of the Sabara published in 1938.

${ }^{1}$ Lord Hailey, An African Survey: A Study of Problems Arising in Africa South of the Sahara (Oxford: Oxford University Press, 1938), 1208.

D. Matasci $(\square)$

University of Lausanne, Lausanne, Switzerland e-mail: Damiano.Matasci@unige.ch

M. B. Jerónimo · H. G. Dores

Centre for Social Studies, University of Coimbra, Coimbra, Portugal

H. G. Dores

e-mail: hugodores@ces.uc.pt

(C) The Author(s) 2020

D. Matasci et al. (eds.), Education and Development in Colonial and Postcolonial Africa, Global Histories of Education, https://doi.org/10.1007/978-3-030-27801-4_1 
In this monumental work, which marked the starting point of a new orientation in British colonial policy, on many issues, the eminent former member of the Indian Civil Service noted the great diversity of policies that were in force not only in the British possessions in Africa but also in the French, Belgian, and Portuguese territories. Variation ruled (at least in the policies proclaimed to be implemented), but the centrality of education in the colonial project was highlighted, at least rhetorically. For sure, the "educability" of the native had been the subject of numerous debates and experiments since the late nineteenth century, frequently shaped by culturalist and racialist arguments in the aftermath of formal abolitionism. In the early twentieth century, they continued, with various motivations and purposes, in different international and colonial contexts. ${ }^{2}$

The same happened with the debates about the usefulness of "native education," at the metropoles and at the colonies. Problems such as the necessity and the utility of the provision of educational services in Africa, for settlers and for the colonial subjects, were the object of numerous appreciations. A diversity of arguments and positions emerged within imperial and international circles in relation to the role that education could or should play in the economic and social transformation of African societies. ${ }^{3}$

\footnotetext{
${ }^{2}$ For instance, for the French case, see Pascale Barthélémy, "L'enseignement dans l'Empire colonial français: une vieille histoire?" Histoire de l'éducation, no. 128 (2010): 5-28; for the British case see Clive Whitehead, "The Historiography of British Imperial Education Policy, Part II: Africa and the Rest of the Colonial Empire," History of Education 34, no. 4 (2005): 441-454; for the Portuguese case, see Miguel Bandeira Jerónimo, "Livros Brancos, Almas Negras. Programas e Discursos (1880-1930)," MA diss., New University of Lisbon, 2000; João Carlos Paulo, "What Does Indigenous Education Mean? Portuguese Colonial Thought and the Construction of Ethnicity and Education," Paedagogica Historica 37, no. 1 (2001): 231-250. See also Julie McLeod and Fiona Paisley, "The Modernization of Colonialism and the Educability of the 'Native': Transpacific Knowledge Networks and Education in the Interwar Years," History of Education Quarterly 56, no. 3 (2016): 473-502. For a landmark see Marc Depaepe and António Nóvoa (eds.), "The Colonial Experience in Education," Paedagogica Historica 31, supplement 1 (1995).

${ }^{3}$ Barnita Bagchi, Eckhardt Fuchs, and Kate Rousmaniere (eds.), Connecting Histories of Education: Transnational and Cross-Cultural Exchanges in (Post)Colonial Education (New York: Berghahn Books, 2014). For a comparative assessment, see Peter Kallaway and Rebecca Swartz (eds.), Empire and Education in Africa: The Shaping of a Comparative Perspective (New York: Peter Lang, 2016). On the postcolonial period, see Céline LabruneBadiane, Marie-Albane de Suremain, and Pascal Bianchini (dir.), L'école en situation postcoloniale (Paris: L'Harmattan, 2012).
} 
Paradigms such as "adapted," "vocational," "mass," or "fundamental" education, elaborated within long-standing and enduring racialized frameworks, had a significant role in the ways in which European colonial administrations strove to improve the living standards of local populations, so to legitimize imperial rule or even enable some forms of controlled self-government. Similarly, education was also a crucial realm for newly independent countries, as part of ambitious political and socioeconomic modernization schemes.

Despite the importance of these issues, the burgeoning historiography focused on "development" has not reflected this fact accordingly. ${ }^{5}$ Admittedly, economic historians have attempted to assess the impact of education on current macroeconomic performances of African countries. ${ }^{6}$ Using quantitative methods,

4 "Development" is an ambiguous and contentious notion. According to Joseph Hodge, this notion refers to "an intentional, organized intervention in collective affairs according to a general (if not universal) standard of improvement." It encompasses two distinct poles: raising production and productivity, on the one hand, and raising the living standards of people regarded as backward or underdeveloped, on the other. Joseph M. Hodge, Gerald Hodl, and Martina Kopf (eds.), Developing Africa: Concepts and Practices in TwentiethCentury Colonialism (Manchester: Manchester University Press, 2014): 3.

${ }^{5}$ For some notable contributions on the history of development in Africa, see Hodge, Hodl, and Kopf (eds.), Developing Africa; Peter J. Bloom, Stephan F. Miescher, and Takyiwaa Manuh (eds.), Modernization as Spectacle in Africa (Bloomington and Indianapolis: Indiana University Press, 2014). For general assessments, see Erez Manela and Stephen Macekura (eds.), The Development Century: A Global History (Cambridge: Cambridge University Press, 2018); Frederick Cooper and Randall Packard (eds.), International Development and the Social Sciences (Berkeley: University of California Press, 1997). See also the synthesis provided by Corinna Unger, "Histories of Development and Modernization: Findings, Reflections, Future Research," H-Soz-Kult, 9.12.2010, http://hsozkult.geschichte.hu-berlin.de/forum/2010-12-001; Joseph M. Hodge, "Writing the History of Development (Part 1: The First Wave)," Humanity 6, no. 3 (2015): 429-463; Hodge, "Writing the History of Development (Part 2: Longer, Deeper, Wider)," Humanity 7, no. 1 (2016): 125-174. Another crucial text is Nick Cullather, “Development? It's History,” Diplomatic History 24, no. 4 (2000): 641-653.

${ }^{6}$ Among other important contributions see Gareth Austin, "Développement économique et legs coloniaux en Afrique," Revue internationale de politique de développement, no. 1 (2010): 11-32; Ewout Frankema, "The Origins of Formal Education in Sub-Saharan Africa: Was British Rule More Benign?” European Review of Economic History 16, no. 4 (2012): 335-355; Ewout Frankema, "Colonial Education and Postcolonial Governance in the Congo and Indonesia," in Colonial Exploitation and Economic Development: The Belgian Congo and the Netherlands Indies Compared, ed. by Ewout Frankema and F. Buelens (London: Routledge, 2013): 153-177. 
they have identified historical factors that could explain contemporary inequalities, such as transatlantic slavery trade, the presence of missions' stations or the degree of public investments in institutions like schools. ${ }^{7}$ These studies demonstrate, among other things, the relevance of longterm historical analysis to the understanding of developmentalism. ${ }^{8}$ However, they often fail to fully appreciate the complex, changing and sometimes contradictory processes that shaped the link between education and socioeconomic change. ${ }^{9}$

${ }^{7}$ The literature is already vast, and compelling. For some major references, see, among others, Daron Acemoglu, Simon H. Johnson, and James A. Robinson, "The Colonial Origins of Comparative Development: An Empirical Investigation," American Economic Review 91, no. 5 (2001): 1369-1401; Leander Heldring and James Robinson, "Colonialism and Development in Africa," NBER Working Paper, 18566 (2012); Emmanuel Akyeampong, Robert H. Bates, Nathan Nunn, and James A. Robinson (eds.), Africa's Development in Historical Perspective (New York: Cambridge University Press, 2014); Stelios Michalopoulos and Elias Papaioannou (eds.), The Long Economic and Political Shadow of History, vol. II: Africa and Asia (London: CEPR Press, 2017). On the role of the state, see Matthew Lange, Lineages of Despotism and Development: British Colonialism and State Power (Chicago: University of Chicago Press, 2009); Elise Huillery, "History Matters: The Long-Term Impact of Colonial Public Investments in French West Africa," American Economic Journal: Applied Economics 1, no. 2 (2009): 176-215; Denis Cogneau, Yannick Dupraz, and Sandrine Mesplé-Somps, "African States and Development in Historical Perspective: Colonial Public Finances in British and French West Africa," Paris School of Economics Working Paper (2018). On missions, central to understand the question of education, see Nathan Nunn, "Gender and Missionary Influence in Colonial Africa," in Africa's Development in Historical Perspective, ed. by E. Akyeampong, R. Bates, N. Nunn, and J. Robinson, 489-512; Johan Fourie and Christie Swanepoel, "When Selection Trumps Persistence: The Lasting Effect of Missionary Education in South Africa," Tijdschrift voor Sociale en Economische Geschiedenis 12, no. 1 (2015): 1-29; Julia Cagé and Valeria Rueda, "The Devil Is in the Detail: Christian Missions' Heterogeneous Effects on Development in Sub-Saharan Africa," in The Long Economic and Political Shadow of History, ed. by S. Michalopoulos and E. Papaioannou, vol. II, 98-108; Remi Jedwab, Felix Meier $\mathrm{zu}$ Selhausen, and Alexander Moradi, The Economics of Missionary Expansion: Evidence from Africa and Implications for Development. CSAE Working Paper, Centre for the Study of African Economies, University of Oxford, 2018; Francisco A. Gallego and Robert D. Woodberry, "Christian Missionaries and Education in Former African Colonies: How Competition Mattered," Journal of African Economics, no. 3 (2010): 294-329.

${ }^{8}$ Nathan Nunn, "The Importance of History for Economic Development," Annual Review of Economics 1, no. 1 (2009): 65-92.

${ }^{9}$ An important point here is, of course, the reliability of the sources, mainly statistical, upon which these important exercises are based on and, therefore, the robustness of their conclusions. From the accurate study of their production to the critical appreciation of 
This collective edited volume aims to fill this gap. It contributes to a closer interaction between the historiographies and historical trajectories of education and development, pointing to the co-constitution of arguments, debates, and policies focused on both colonial and postcolonial Africa. Drawing on empirical and multilingual enquiries, the contributors examine a vast array of actors, discourses, and projects aiming at the mise en valeur and at the socioeconomic transformation-in some circles seen as "the theory of modernization" 10 - of the African continent and respective societies. Several key aspects of such a process will be highlighted, including transnational and inter-imperial entanglements, as well as continuities and ruptures between the colonial era and the post-independence years. The question at stake is to determine how and why the raise of educational standards of indigenous populations and the training of local elites became a key feature within imperial, national, and international agendas, in different ways and with distinct timings, as part of evolving development theses and projects produced by European administrations, missionaries, intergovernmental organizations, as well as African, Western, and Eastern countries.

During the twentieth century, three phases-or critical junctures-can be identified, during which the economic and social goals of education were profoundly reconfigured and its place in projects of societal and economic transformation evolved. ${ }^{11}$

their use in time, the quality of statistical information produced by empire states and colonial administrations needs to be constantly scrutinized. The thought-provoking arguments offered by Morten Jerven, Poor Numbers: How We Are Misled by African Development Statistics and What to Do About It (Ithaca, NY: Cornell University Press, 2013) can be useful on many ways.

${ }^{10}$ David C. Engerman and Corinna R. Unger, "Introduction: Towards a Global History of Modernization," Diplomatic History 33, no. 3 (2009): 375-385; David Ekbladh, The Great American Mission: Modernization and the Construction of an American World Order, 1914 to the Present (Princeton: Princeton University Press, 2010).

${ }^{11}$ Needless to say, this chronology does not aim at being exhaustive or to neatly organize the historical dynamics of the process under analysis. The political, sociocultural, and economic goals of education varied significantly from colonial empire to colonial empire, although some common features may be identified. 


\section{On Adaptability and “Useful Producers” (1900-1930)}

The first phase, spanning the period between 1900 and 1930, coincided with the introduction of the first "native" educational systems in the wake of the scramble for Africa which had started in the last decades of the nineteenth century. These systems, which worked as such more de jure than de facto, were dominated by missionaries, widely acting in behalf of colonial authorities (although a clear distinction between Catholic and Protestant dynamics must be made in this respect). ${ }^{12}$ From the beginning of modern missionary expansion (at least since the sixteenth century), education was an essential aspect of the activities of the missions, although conversion was surely more pivotal (in some cases, the two might be closely related). For Catholic and Protestant missionaries, conversion required learning local languages, teaching European languages, and adapting, sometimes forcefully, local concepts to Christian beliefs (and, often, vice versa). Missionaries carried more than a religious vision with them. They also embodied news ways of understanding sociocultural difference, and in different ways, they promoted a complex and multilayered set of assumptions commonly associated with the idea of "civilising mission." Furthermore, they often promoted a concept of "education through labour," intermingled with arguments of African purported laziness and idleness, which governed European perspective about African populations during colonial times. As some of the texts in this volume show, missions acquired a significant, frequently criticized, centrality in the provision of educational services to African populations, reproducing, at least on paper, European schooling models (see, for instance, the French and the Belgian cases). Needless to say,

\footnotetext{
${ }^{12}$ For the relationship between political and religious authorities in imperial and colonial contexts, see, among many others: Andrew Porter, Religion Versus Empire? British Protestant Missionaries and Overseas Expansion, 1700-1914 (Manchester: Manchester University Press, 2004); Brian Stanley, The Bible and the Flag: Protestant Missions and British Imperialism in the Nineteenth and Twentieth Centuries (Leicester: Appollos, 1990); Norman Etherington (ed.), Missions and Empire (Oxford: Oxford University Press, 2005); Owen White and J. P. Daughton (eds.), In God's Empire: French Missionaries and the Modern World (Oxford: Oxford University Press, 2012); Miguel Bandeira Jerónimo, A Diplomacia do Império. Politica e Religião na partilha de África (1820-1890) (Lisbon: Edições 70, 2012); Hugo Gonçalves Dores, A missão da república: Política, religião e o império colonial Português (1910-1926) (Lisbon: Edições 70, 2015).
} 
and despite some perspectives that obscure this fact, their role varied in time and space, and it is not easily described and classified. Their actual intervention was diverse, and caution is needed when reading the existing statistics and reports. Like many other examples regarding imperial and colonial action, the rhetoric of "conversion" was frequently contradicted by closer inspections, including by the missionary or ecclesiastical actors themselves. The competition for "souls," among missionary societies, Christian denominations, and between Church and State, led to significant overestimations (some uncritically reproduced in contemporary assessments). Finally, their impact on forms of belief and social practices, on education and development, at the time and throughout time, was also plural, requiring much more than simple forms of causality.

The "effective occupation" proved hard to succeed, and clearly, the priorities of imperial governments and colonial administration rested not on the significant provision of educational services. Regarding the latter, this period was characterized not so much by the extent of practical achievements, despite the considerable, and formal, expansion of missionary schools, as by intense debates on the "content" of education and, in particular, its adaptation to the putative social, economic, and cultural specificities of African populations and territories. ${ }^{13}$ The general goal was to strike a balance between the imperatives of "moral conquest"as conceptualized in 1917 by Georges Hardy, Director of Education in West French Africa ${ }^{14}$-and the concerns linked to the "detribalization" and "social displacement" caused by a supposedly too abstract and literary education which emulated the metropolitan one. Given the need to sustain the efforts to foster "legitimate commerce," in relation to the protracted dynamics of abolition of slave trade and slavery, and the need to regulate the uses of coerced and "contract" labor, the ponderations about "native education" also appeared connected to the debates on how to guarantee the availability of African manpower. Faced with these problems, the solutions envisaged and the educational models put in place by European colonial powers were particularly diverse throughout

\footnotetext{
${ }^{13}$ For instance, Udo Bude, "The Adaptation Concept in British Colonial Education," Comparative Education 19, no. 3 (1983): 341-355.

${ }^{14}$ Georges Hardy, Une conquête morale. L'enseignement en AOF (Paris: Armand Colin, 1917).
} 
the territories. ${ }^{15}$ There was no coherent and unified educational project, but rather different and changing realities from one colony to another. The "moral conquest" meant slightly different things from colonial empire to colonial empire, from colony to colony, from administration to administration. Moreover, as happened with many other topics, the distance between proclaimed educational policies and the actual administrative practices was frequently unsurmountable.

After the First World War, colonial education progressively acquired new objectives, partially in response to the new League of Nations' concept of "trusteeship" and the growing native demand for education (which also varied from one context to another). ${ }^{16}$ The French Minister for Colonies Albert Sarraut, for example, placed training and education in the program for the mise en valeur of African territories, which covered port and river development, railway and road construction, and also health care improvement. In this framework, education was supposed to not only be made widely available to the rural masses, but also be focused on practical objectives. It had to convey "practical experimental" notions, orient native children toward "manual trades," and prepare "useful producers" (producteurs utiles). ${ }^{17}$ This practical emphasis was used by many, in diverse ways, some to justify the opposition to the role played by the religious entities in education in colonial contexts (partially a projection of ongoing conflicts at the metropole), while others to foster ideas of (forced) labor as quintessentially an educational instrument. This was noticeable at the metropoles but it was also manifest in the debates regarding the possibilities of economic change or the suppression of slavery and implementation of new forms of labor exaction within the League of Nations. ${ }^{18}$ Similar considerations to those of Sarraut were also

${ }^{15}$ Ana Isabel Madeira, "Portuguese, French and British Discourses on Colonial Education: Church-State Relations, School Expansion and Missionary Competition in Africa, 1890-1930," Paedagogica Historica 41, nos. 1-2 (2005): 31-60.

${ }^{16}$ Susan Pedersen, The Guardians: The League of Nations and the Crisis of Empire (Oxford: Oxford University Press, 2015). On education, see J. M. Barrington, "The Permanent Mandates Commission and Educational Policy in Trust Territories," International Review of Education 22, no. 1 (1976): 88-94.

${ }^{17}$ Albert Sarraut, La mise en valeur des colonies françaises (Paris: Payot et Cie, 1923): 401.

${ }^{18}$ Miguel Bandeira Jerónimo, The "Civilizing Mission" of Portuguese Colonialism, 1870 1930 (Basingstoke: Palgrave Macmillan, 2015), 147-150. See also Susan Pedersen, The Guardians. For a later period, see Frederick Cooper, Décolonisation et travail en Afrique. L'Afrique britannique et française, 1935-1960 (Paris: Karthala, 2004). 
expressed by Lord Lugard in his work The Dual Mandate, published in 1922. This influential volume stated that the goal of village schools was to "improve the village craftsmen and agriculturists, to raise the standard of life, comfort, and intelligence in the village community."19

The emergence of this "developmentalist" discourse accompanied the introduction of forms of education through labour, in a context marked by the intensification of the internationalization of imperial and colonial affairs, not least about the "conditions analogous to slavery." 20 For instance, those forms followed the example of the coercive measure called deuxieme portion du contingent ("second part of the contingent") which was created in 1926 in French West Africa (see the chapter of Romain Tiquet). The first vocational and technical study programs were also established-for example, in North Africa (see the chapter of Michael A. Kozakowski) and in the German colonies (see the chapter of Jakob Zollmann) - even though they remained very limited and were sometimes restricted to white population. ${ }^{21}$

The publication in 1922 and 1925 of two reports on African education commissioned by the American philanthropic foundation PhelpsStokes Fund (PSF) represented an important turning point in the international and (inter)imperial formulation of colonial educational policies, although its impact is yet to be comparatively studied. The transatlantic circulation of educational models and potential policies (and other

${ }^{19}$ Frederick Lugard, The Dual Mandate in British Tropical Africa (Edinburgh: William Blackwood and Sons, 1922): 444.

${ }^{20}$ Frederick Cooper, "Conditions Analogous to Slavery: Imperialism and Free Labor Ideology in Africa," in Beyond Slavery: Explorations of Race, Labor, and Citizenship in Postemancipation Societies, ed. by Frederick Cooper, Thomas C. Holt, and Rebecca J. Scott (Chapel Hill: University of North Carolina Press, 2000), 107-149; Miguel Bandeira Jerónimo, "A League of Empires: Imperial Political Imagination and Interwar Internationalisms," in Internationalism, Imperialism and the Formation of the Contemporary World, ed. by Miguel Bandeira Jerónimo and José Pedro Monteiro (London: Palgrave Macmillan, 2017), 87-126. For the dynamics of internationalization, see also, for instance, Pierre Singaravelou, "Les stratégies d'internationalisation de la question coloniale et la construction transnationale d'une science de la colonisation à la fin du XIXe siècle," Monde(s) 1, no. l (2012): 135-157; Veronique Dimier, "L'internationalisation du débat colonial: rivalités autour de la Commission Permanente des Mandats," Outre-mers 89, nos. 336-337 (2002): 333-360.

${ }^{21}$ Stéphane Lembré, "L'enseignement technique et professionnel dans l'Algérie coloniale, du territoire à l'atelier (1866-1958)," Histoire de l'éducation, no. 147 (2017): 91-117. 
Alabamas in Africa) was differently engaged by different colonial powers. $^{22}$ Even those, such as the Portuguese, that were not the primordial focus of the study-not least because of the close connections between the state and the Catholic Church and of the convoluted relationship with foreign missions since the mid-nineteenth century-nonetheless reacted to the reports' findings. ${ }^{23}$ Written in the wake of missions carried out by Thomas Jesse Jones, a leading member of the PSF and a former director of the Research Department of Hampton Institute in Virginia (one of the pioneer colleges for black students in the United States), the reports put forward precise suggestions with regard to adapting local schools systems to "the educational needs of Africa," in particular "those pertaining to the hygienic, economic, social, and religious conditions of the Native people."24

Taking up the educational model used with black Americans since the mid-nineteenth century, Jones's proposed policy could be summed up into four categories which he called "The Four Essentials of Education": health, home life training, industry (including agriculture), and recreation. ${ }^{25}$ Education was meant to serve primarily the needs of the community, particularly agricultural and industrial ones, rather than provide literary knowledge that had supposedly little relevance or utility in African economic life. These utilitarian principles were embraced, directly or indirectly, by many colonial administrations (once again, for different reasons, with distinct aims). ${ }^{26}$ In 1925 , for example, the first report

\footnotetext{
${ }^{22}$ For a now classic study of these transatlantic connections, see Andrew Zimmerman, Alabama in Africa: Booker T. Washington, the German Empire, and the Globalization of the New South (Princeton: Princeton University Press, 2010).

${ }^{23}$ Thomas Jesse Jones, Education in Africa: A Study of West, South, and Equatorial Africa by the African Education Commission (New York: Phelps-Stokes Fund, 1922), and Education in East Africa (New York: Phelps-Stokes Fund, 1925).

${ }^{24}$ Jones, Education in Africa, xvi.

${ }^{25}$ Julia Bates, "U.S. Empire and the 'Adaptive Education' Model: The Global Production of Race," Sociology of Race and Ethnicity 5, no. 1 (2019): 41-54.

${ }^{26}$ Sybille Küster, “'Book Learning' Versus 'Adapted Education': The Impact of PhelpsStokesism on Colonial Education Systems in Central Africa in the Interwar Period," Paedagogica Historica 43, no. 1 (2007): 79-97; Maud Seghers, "Phelps-Stokes in Congo: Transferring Educational Policy Discourse to Govern Metropole and Colony," Paedagogica Historica 40, no. 4 (2004): 455-477; Miguel Bandeira Jerónimo, The "Civilizing Mission" of Portuguese Colonialism, 1870-1930 (Basingstoke: Palgrave Macmillan, 2015): 109-133.
} 
submitted to the British Colonial Office by the Advisory Committee on Native Education in British Tropical Africa emphasized that education "should be adapted to the mentality, aptitudes, occupations and traditions of the various peoples" 27 and that it had to help improve agriculture, "native industries," and health. Adopting these principles, which were also amply discussed within international and intercolonial bodies ${ }^{28}$ new school institutions were created, some of them famous, such as the Achimota College in the Gold Coast. ${ }^{29}$ In French West Africa, in the early 1930s, Governor General Jules Brévié and school inspector Albert Charton recommended changing "village schools" to "rural schools" (écoles rurales), where an important place would be given to agricultural education (with the creation, for example, of school gardens) and to manual trades. ${ }^{30}$

This reorientation of educational policies came up against several problems. On the one hand, the paradigm of "adapted education" was often met with hostility among African elites, who saw it as education "on the cheap" devoid of attractiveness and any prospect of social promotion, as reported by Léopold Sédar Senghor in 1937.31 Its "practical" positive consequences were questioned; its social, cultural, and economic effects criticized. What "development" would arise from it? Who would benefit from it? What did its implementation say about the ways the colonizers saw the colonized? On the other hand, there was no large-scale funding for the development of colonial school systems. Budgetary restrictions and policy options, for political but also sociocultural reasons, justified that fact, among other aspects. Overall, school-enrollment rates were very low, although

${ }^{27}$ Advisory Committee on Native Education in the British Tropical African Dependencies, Education Policy in British Tropical Africa (London: H. M. Stationery Office, 1925), 4.

${ }^{28}$ See Institut Colonial International, L'enseignement aux indigènes. Rapports préliminaires, XXIe session, Paris, 5-8 mai 1931 (Bruxelles: Établissements généraux d'imprimerie, 1931).

${ }^{29}$ Gita Steiner-Khamsi and Hubert Quist, "The Politics of Educational Borrowing: Reopening the Case of Achimota in British Ghana," Comparative Education Review 44, no. 3 (2000): 272-299.

${ }^{30}$ Harry Gamble, "Peasants of the Empire. Rural Schools and the Colonial Imaginary in 1930s French West Africa,” Cahiers d'études africaines 195 (2009): 775-804.

${ }^{31}$ See Paule Brasseur, "À propos du congrès de l'évolution culturelle des peuples coloniaux Paris, 1937," Journal des Africanistes 49, no. 2 (1979): 145. 
there were significant territorial differences. ${ }^{32}$ Despite the rhetoric around the mise en valeur of colonies, education remained a relatively neglected area of public investment, both for economic and political reasons. But the "educability" of the "natives" never ceased to be pondered. ${ }^{33}$ This can be said of every European colonial empire in Africa. Arguments and debates abounded, numerous policies were proclaimed, but resources, human and financial, were scarce, and unevenly distributed. As a result, in a moment in which they were internally debating how to position themselves in the world born out of Versailles, missionaries continued to play a leading part, especially in British Africa, Belgian Congo, and the Italian East African colonies (see the chapter of Caterina Scalvedi). In the Portuguese case similar dynamics occurred, although the scarcity of educational services was matched by the feebleness of ecclesiastical and missionary ones, despite the rhetoric of the "civilizing mission." 34

\section{Development, After Depression (1930-1960)}

The debates on the content and goals of colonial education evolved in the 1930s. The decade marked the start of what can be seen as a second phase, lasting until independence. The effects of the Great Depression encouraged more attention being paid to education's economic and social repercussions, including in colonial realms. Together with the first signs of greater state intervention in colonial science research, new ideas on colonial education started to develop within many missionary and philanthropic circles (in this regard, see Peter Kallaway's timeline at the end of Chapter 2). ${ }^{35}$ International missionary networks, grouped together within the International Missionary Council (1921) led by Joseph Oldham, devoted several of their conference sessions to

\footnotetext{
${ }^{32}$ Here, again, we should take into consideration the problematic reliability of colonial statistics.

${ }^{33}$ Clive Whitehead, "The Historiography of British Imperial Education Policy, Part II," 444.

${ }^{34}$ Ana Isabel Madeira, "Ler, escrever e orar: Uma análise histórica e comparada dos discursos sobre a educação, o ensino e a escola em Moçambique, 1850-1950," PhD diss., University of Lisbon, 2007; Miguel Bandeira Jerónimo, A diplomacia do imperialismo; Hugo Gonçalves Dores, A missão da república.

${ }^{35}$ Christopher Bonneuil, "Development as Experiment: Science and State Building in Late Colonial and Postcolonial Africa, 1930-1970," Osiris 15 (2000): 1501-1520.
} 
the links between the education and welfare of African populations. ${ }^{36}$ For instance, in 1926, in Le Zoute, Belgium, a meeting devoted to the "Christian mission" in Africa was clear on the statement that was widely acknowledged "not only by missionaries but by administrators" that "the future" of Africa was associated with "the moral, physical and intellectual development of the African peoples." As its reporter wrote, at the conference everyone "expressed its economic faith in this sentence." And he added, continuing to echo the general consensus at the meeting: "Europeans of themselves cannot carry out that development. The Africans as they were, and still are to a very large extent, cannot carry it out. Only by a process of education-which includes work, but much more - can they be fitted to take their share in developing Africa. Physical and moral improvement of the African is a necessary condition of the economic development of the continent." 37 On the Catholic side, similar points could be made, perhaps with more emphasis on religious education and conversion (see the chapter of Caterina Scalvedi). European humanitarian organizations too saw in the expansion of education a means to combine civilizational demands with native "well-being." At the 1931 International Conference on African Children held in Geneva by the Save the Children International Union, the Swiss missionary and ethnographer Henri-Alexandre Junod, president of the Bureau international pour la défense des indigènes, stated that education was an essential means not only for achieving economic progress in Africa, but also for "certain elements of civilization," following the example of norms of hygiene, to reach "as far as the lower levels of the population." 38

\footnotetext{
${ }^{36}$ Peter Kallaway, "Education, Health, and Social Welfare in the Late Colonial Context: The International Missionary Council and Educational Transition in the Interwar Years with Specific Reference to Colonial Africa," History of Education 38, no. 2 (2009): 217-246.

${ }^{37}$ Edwin W. Smith, The Christian Mission in Africa, a Study Based on the Work of the International Conference at Le Zoute, Belgium, September 14th to 21st, 1926 (London: International Missionary Council, 1926): 90.

${ }^{38}$ State Archives of the Canton of Geneva, Archives privées, 92-4-9. Conférence internationale pour l'enfance africiane. Compte rendu (1932): 55-60. On this conference, see Dominique Marshall, "Children's Rights in Imperial Political Cultures: Missionary and Humanitarian Contributions to the Conference on the African Child of 1931," The International Journal of Children's Rights 12, no. 3 (2004): 273-318.
} 
This new outlook led the way to the great reorientations taking place in the 1940s. The Mass Education in African Society report published by the Colonial Office in 1944 provided a new conceptual basis for rethinking the role of education in raising living standards. As emphasized by one of its authors, Margaret Wrong, secretary to the International Committee on Christian Literature for Africa, "it has been proved that the attainment of literacy makes people aware of the need for social and economic improvements, and therefore they will co-operate more readily with welfare and other agencies working on these lines." 39 Thus, the spread of school education, the fight against illiteracy, and the improvement of adult education were directly linked with the economic and social modernization of African colonies, as attested also by the conclusions of the Brazzaville conference convened in 1944 by the authorities of Free France. ${ }^{40}$ Thanks to the Colonial and Development Welfare Act (CDWA)-adopted in 1940 and revised in 1945-as well as the creation of the Fonds d'investissement pour le développement économique et social (FIDES) in France (1946) and the Fonds du bien-être indigene in Belgium (1947, followed by the Plan décennal pour le développement économique et social du Congo belge in 1949), significant financial resources were growingly invested in the educational sector. Education represented between 6 and $7 \%$ of the total budget of the FIDES, and about $20 \%$ of the budget of the CDWA (100 million pounds over 10 years). Part of a new "modernising mission," 41 colonial development policies took shape around two major axes: on the one hand, building schools and expanding the educational offer, including at university level by creating of colonial universities and increasing the number of scholarships for studying in the metropole (see the chapter of Hélène Charton); on the other hand, European administrations carried out more delimited projects targeting the "community development" of towns and rural

\footnotetext{
${ }^{39}$ Margaret Wrong, "Mass Education in Africa," African Affairs 43, no. 172 (1944): $105-111$.

${ }^{40}$ David E. Gardinier, "Les recommandations de la Conférence de Brazzaville sur les problèmes d'éducation," in Brazzaville, janvier-février 1944: aux sources de la décolonisation, ed. by Institut Charles-de-Gaulle (Paris: Plon, 1988): 170-180.

${ }^{41}$ See the Special Issue "Modernizing Missions: Approaches to the 'Developing' the Non-Western World After 1945," Journal of Modern European History 8, no. 1 (2010). For the French Empire, see Ed Naylor (ed.), France's Modernising Mission: Citizenship, Welfare and the Ends of Empire (Basingstoke: Palgrave Macmillan, 2018).
} 
villages. ${ }^{42}$ Such was the case, for example, of the mass education and adult education experiments conducted in French and British Africa from the late 1940s, in rural centers in Belgium Congo, or in Algerian Centres sociaux which were created in 1955 and were active throughout the war (see the chapter of Brooke Durham).

These new priorities echoed the new international context emerging after the Second World War, and in particular the United Nations agenda. Indeed, UN specialized agencies, particularly the United Nations Educational, Scientific and Cultural Organization (UNESCO), embarked on ambitious programs for providing technical assistance to "underdeveloped" countries. ${ }^{43}$ Naturally, education became a recurrent topic. ${ }^{44}$ In this context, senior officials such as Julian Huxley (first Director General of UNESCO) and John Bowers (head of the Department of Fundamental Education) fostered a vast conceptual undertaking for the purpose of formulating an educational doctrine specially designed for countries of the Global South. ${ }^{45}$ Known under the name of "Fundamental Education," it was tested beginning with 1947 within several pilot projects carried out in Haiti, Nyasaland, and China. ${ }^{46}$ The introduction of a global agenda that was centered on the

${ }^{42}$ For “community development," see Daniel Immerwahr, Thinking Small: The United States and the Lure of Community Development (Cambridge: Harvard University Press, 2014).

${ }^{43}$ Amy L. S. Staples, The Birth of Development: How the World Bank, Food and Agriculture Organization, and World Health Organization Changed the World, 1945-1965 (Kent: Kent State University Press, 2006); Daniel Maul, Human Rights, Development and Decolonization: The International Labour Organization, 1940-1970 (London: Palgrave Macmillan, 2012); Corinna R. Unger, Marc Frey, and Sonke Kunkel (eds.), International Organizations and Development (1945-1990) (Basingstoke: Palgrave Macmillan, 2014). See also Corinna Unger, International Development: A Postwar History (London: Bloomsbury, 2018).

${ }^{44}$ Phillip W. Jones, International Policies for Third World Education: Unesco, Literacy, and Development (London/New York: Routledge, 1988); Colette Chabbott, Constructing Education for Development: International Organizations and Education for All (New York: Routledge, 2003).

${ }^{45}$ UNESCO, Fundamental Education: Common Ground for all Peoples: Report of a Special Committee to the Preparatory Commission of Unesco (Paris: UNESCO, 1946).

${ }^{46}$ Joseph Watras, "UNESCO's Programme of Fundamental Education, 1946-1959," History of Education 39, no. 2 (2010): 219-237; For the Haiti's project (Marbial Valley), see: Chantalle F. Verna, "Haiti, the Rockfeller Foundation, and UNESCO's Pilot Project in Fundamental Education, 1948-1953," Diplomatic History 40, no. 2 (2016): 269-295. 
fight against illiteracy and educational inequalities throughout the world, including "non-self-governing territories," stimulated the institutionalization of new forms of technical cooperation of an intercolonial nature which gained in importance beginning with the late 1940s (see the chapter of Hugo Gonçalves Dores and Miguel Bandeira Jerónimo). ${ }^{47}$ Thus, in the context of a "crisis of the empires," 48 education became an important area for certifying, within national and international circles, the metropoles' commitment to the "well-being" and living standards of the colonized populations.

\section{Competing Projects (1960-1990)}

The independence wave sweeping over the early 1960s opened up a new phase marked by the political aspirations of the new independent states and Cold War tensions. Placed at the centre of the demands made by nationalist and pan-African movements, education became a priority for the new African governments. In this regard, decolonization raised specific problems: Low school-enrollment rates and high illiteracy rates, coupled with the departure of colonial senior staff, posed the immediate problem of a lack of qualified staff in administrations and certain economic sectors. Accordingly, the formation of a national elite and intelligentsia became a major goal in support of economic modernization and nation-building in African countries (see the chapter of Eric Burton), along with the promotion of mass schooling.

In a context that some sociologists have described as a "world educational revolution" 49 characterized by a spectacular increase in school-enrollment rates, development aid for Africa became a major issue in

\footnotetext{
${ }^{47}$ On education see Damiano Matasci, "Une 'UNESCO africaine'? Le ministère de la France d'Outre-mer, la coopération éducative intercoloniale et la défense de l'Empire, 1947-1957," Monde(s), no. 13 (2018): 195-214, and “Assessing Needs, Fostering Development: UNESCO, Illiteracy and the Global Politics of Education (1945-1960)," Comparative Education 53, no. 1 (2017): 35-53; On health see Jessica Lynne Pearson, The Colonial Politics of Global Health: France and the United Nations in Postwar Africa (Harvard: Harvard University Press, 2018); Vincent Bonnecase, La pauvreté au Sabel: du savoir colonial à la mesure internationale (Paris: Karthala, 2011).

${ }^{48}$ Martin Thomas, Bob Moore, and Larry Butler, Crises of Empire (London: Hodder Education, 2008).

${ }^{49}$ John Meyer et al., "The World Educational Revolution, 1950-1970," Sociology of Education 50 (1977): 242-258.
} 
North-South relations. Seeking to establish and defend their economic and cultural sphere of influence, the former metropoles quickly set up cooperation agreements which especially provided for financial contributions toward building schools or for sending European staff to secondary education and higher education institutions. ${ }^{50}$ Foreign staff and coopérants occupied an important place within educational systems, in many countries reaching levels as high as $80-90 \%{ }^{51}$ Starting with the early 1960s and the launch of the "Decade of Development," international organizations also played an important role in the assessment of educational needs, in the "africanization" of structures and programs, as well as the planning of long-term educational expansion, as attested by the plan developed at the Addis Ababa conference in May 1961. ${ }^{52}$ Last but not least, the two superpowers-United States and Soviet Unioninvested massively in programs meant to encourage the inflow of African students into their own countries. The philanthropic foundations Ford, Rockefeller, and Carnegie were particularly active in this respect. ${ }^{53}$ Similarly, Eastern Bloc countries set up several programs for training future African elites. ${ }^{54}$ Higher education in particular became one of the areas where "socialist solidarity" gained expression (as pointed out in the chapter of Alexandra Piepiorka), especially in the form of sending experts on-site or creating ad hoc institutions such as Patrice Lumumba University in Moscow in 1960.55

${ }^{50}$ Laurent Manière, "La politique française pour l'adaptation de l'enseignement en Afrique après les indépendances (1958-1964)," Histoire de l'éducation, no. 12 (2010): 163-190; Samy Mesli, "French Coopération in the Field of Education (1960-1980): A Story of Disillusionment," in Francophone Africa at Fifty, ed. by Tony Chafer and Alexander Keese (Manchester: Manchester University Press, 2013): 120-134.

${ }^{51}$ André Labrousse, "La France et l'aide à l'éducation aux États africains et malgache," Cabiers de l'IIPE, no. 22 (1971): 115-116.

${ }^{52}$ Jones, International Policies for Third World Education.

${ }^{53}$ Corinna Unger, "The United States, Decolonization and the Education of Third World Elites," in Elites and Decolonization in the Twentieth Century, ed. by Jost Dülffer and Marc Frey (Basingstoke: Palgrave Macmillan, 2011): 241-261; Ludovic Tournès and Giles Scott-Smith (eds.), Global Exchanges: Scholarship Programs and Transnational Circulations in the Modern World (New York: Berghahn Books, 2017).

${ }^{54}$ For case studies, see Eric Burton (ed.), "Socialisms in Development," Journal für Entwicklungspolitik XXXIII, no. 3 (2017).

${ }^{55}$ Constantin Katsakioris, "Creating a Socialist Intelligentsia: Soviet Educational Aid and Its Impact on Africa (1960-1991)," Cabiers d'études africaines 2, no. 226 (2017): 259-288. 
Two aspects pertaining to the postcolonial period need to be emphasized. On the one hand, developmentalist discourses and practices were often part of a profound continuity with the colonial era. For instance, experts who had worked for colonial administrations in the 1940s and 1950s were, for example, mobilized as consultants by African governments or as specialists by international organizations. ${ }^{56}$ In several respects, development aid, whether of a bilateral or multilateral nature, became a way to "recycle" the empire. ${ }^{57}$ Similarly, the extracurricular measures for training young people and "getting them into work" that were put in place by African governments after independence drew directly on experiments carried out during the colonial period (as showed in the chapter of Romain Tiquet). On the other hand, development aid through education became one area where Cold War tensions and rivalries crystallized. ${ }^{58}$ In this sense, postcolonial Africa represented an arena of competing projects which lay at the centre of global interactions between knowledge and players, where repertoires and paradigms that were tested there evolved based on the dealings between governments and foreign-aid players.

The contributions gathered in this volume deal with these long historical trajectories by drawing on several local case studies based on in-depth archival research. The authors have looked at various geographical spaces - ranging from the French, British, German, and Italian empires to independent countries such as Mali, Senegal, Mozambique, and Tanzania. All levels of education are investigated, from primary to university education, including extracurricular education. Taken as a whole, the chapters allow us to better understand the specificities of each of the three critical junctures presented above. Certainly, it would be possible to increase the number of case studies and territories under observation in order to identify other stakeholders, discourses, practices, and legacies. For example, the role of international organizations should be further examined, and the same goes for the postcolonial period, which would deserve more detailed case studies. Despite these aspects,

\footnotetext{
${ }^{56}$ Joseph M. Hodge, "British Colonial Expertise, Post-colonial Careering and the Early History of International Development," Journal of Modern European History 8, no. 1 (2010): 24-46.

${ }^{57}$ Véronique Dimier, The Invention of a European Development Aid Bureaucracy: Recycling Empire (Basingstoke: Palgrave Macmillan, 2014).

${ }^{58}$ Odd Arne Westad, La guerre froide globale (Paris: Payot, 2005).
} 
this volume offers a renewed perspective on the successive reconfigurations of the relationship between education and development in Africa, thus helping to open up new research avenues, both on the historiography of development and on the one on colonial education.

\section{Overview: Themes and Problems}

This book is organized around three distinct, but complementary, subthemes. The first part focuses on the link between education and the raise of living standards. The chapters investigate the ways in which education became increasingly linked to issues such as health, nutrition, agriculture, and social welfare, which were relevant topics in the debates on development and human progress of African colonized populations, but also in newly independent countries. In fact, different educational programs were substantially focused on these aspects, envisioning the organization of a new societal environment, with specific consequences in traditional societies. The first chapter, by Peter Kallaway, focuses on the relationships between education and social welfare in British Africa. By following the process of construction of a modern network of educational experts throughout the first half of twentieth century, he highlights different, but often correlated, backgrounds, and elucidates in which way they contributed to debates about colonial education. As Kallaway shows, government officials, missionary organizations (such as the International Missionary Council), and philanthropic institutions were key players in shaping development discourses and practices. Therefore, acknowledging the role of this multitude of actors is essential to understand the complexity and variety of proposals and objectives which dealt with education. Such perspective is emphasized by Brooke Durham. Her chapter focuses on the creation of centres sociaux in French Algeria right before independence. This government-sponsored development initiative pledged to provide "fundamental education" to adults and children, rudimentary medical services, and job training. The centres sociaux constitute one example of the attempts by the imperial and colonial administrations to transform different aspects related to the living of those under colonial rule. Durham explores the limits and possibilities of this initiative, which was supposedly apolitical, during a time of increasing conflict between imperial and nationalist forces. She clearly demonstrates that education was part of, and crucial to, a project of social control. This question is also discussed by Romain Tiquet's chapter, 
which investigates the legacies of French-established second portion $d u$ contingent of French West Africa in the youth civil service implemented in independent Mali and Senegal. Highlighting the "civilizing mission" rhetoric and its defense of education through labour for African populations, Tiquet also argues that postcolonial elites, in both countries, perpetuated these dynamics, in order to foster social control and economic development after independence.

The second part of the volume deals with issues related to the training of workers and future local elites. The chapters highlight the importance of technical and vocational curricula for urban and rural workers while many projects maintained the idea of education through labour and the long-standing racialized assertions of African "laziness" or "idleness." They also point out the ambiguities of that kind of colonial education, which was thought to serve imperial rule and to improve the economic productivity of colonial territories, but in many contexts became determinant to the increase of independence movements. Jakob Zollmann sheds light on agricultural education in German South West Africa, between the end of nineteenth century and the First World War. He examines the discussions about which education policy should be applied to European and African children, defining their role in society, economy, and, by extension, colonial development. The chapter by Caterina Scalvedi explores the monopolizing role played by Catholic missionaries in the building of the first state-sponsored school system in Italian Somalia during the interwar years. Having as background the emergence of a centralized and coercive colonial state, Scalvedi examines the different educational opportunities available to both Italian and African children and how school curricula were closely related to the economic needs of the colony. In this regard, technical and vocational education played a key role. In his contribution, Michael A. Kozakowski shows how French colonial administration sought to use technical and vocational education to induce economic transformation in interwar Morocco. As he argues, vocational education should produce loyal subjects, useful workers for the "Greater France," and, in some way, mitigate the dangers of new social aspirations and resulting conflicts brought by economic development and education. The training of competent economic actors was also a key issue in the postcolonial era, as Eric Burton demonstrates. His chapter analyzes the creation of the Faculty of Engineering of the University of Dar es Salaam as result of a pressing need of modernization and economic development in 1960s Tanzania. The faculty, which 
started as a Soviet endeavor and was later dominated by (West) German support, became an important place where the principles of Tanzanian socialist project-ujamaa-were undermined, throughout a process marked by ideological conflicts on the role of university education in society. If the University was seen as a "hotbed" of revolutionary fervor and leftist radicalism, the faculty was marked by technocratic considerations of manpower planning and careering.

The third and final part of the book examines how the circulation of ideas, people and practices between and beyond empires and nation-states contributed to forge the link between education and "development." It focuses on the ways Africa became an arena of competing projects devised by different actors, from intergovernmental organizations to imperial administrations and other European countries, against the background of the Cold War and decolonization. The chapters highlight the connections and rivalries among this multitude of actors, projects, and institutions, as well as the continuities and ruptures between the colonial and postcolonial periods. They also address education and its instrumental role in the overall developmentalist idea. Hugo Gonçalves Dores and Miguel Bandeira Jerónimo's chapter studies how the Commission for Technical Cooperation in Africa South of the Sahara (CCTA), an inter-imperial organization created in 1950, addressed the problem of colonial education. Tracing the renewed attempts launched by imperial powers to establish some forms of cooperation after the Second World War, the text scrutinizes in which way they sought to use education to reshape their developmentalist strategies, in social and economic fields, and to reinforce their arguments legitimizing imperial rule. Hélène Charton analyzes the university reforms designed by British imperial authorities in the 1940s and its impact on the new social and political agenda of British East Africa. These higher education projects, which include the creation of universities in African territories and the multiplication of scholarships in metropolitan institutions, were, as Charton states, at the heart of postwar modernization policies. By tracing new educational modalities, imperial administrations tried to forge a new local elite and deepen the links between metropole and colony. Finally, Alexandra Piepiorka's text focuses on postcolonial attempts to remodel the colonial university system and to readapt it to the new political and social context. Piepiorka uses the Eduardo Mondlane University (Mozambique) to trace the spirit of "socialist solidarity" in the context of educational aid coming from Eastern countries toward Africa's newly independent nations. 


\section{BIBLIOGRAPHY}

Acemoglu, Daron, Simon H. Johnson, and James A. Robinson. "The Colonial Origins of Comparative Development: An Empirical Investigation." American Economic Review 91, no. 5 (2001): 1369-1401.

Advisory Committee on Native Education in the British Tropical African Dependencies. Education Policy in British Tropical Africa. London: H. M. Stationery Office, 1925.

Akyeampong, Emmanuel, Robert H. Bates, Nathan Nunn, and James A. Robinson, eds. Africa's Development in Historical Perspective. New York: Cambridge University Press, 2014.

Austin, Gareth. "Développement économique et legs coloniaux en Afrique." Revue internationale de politique de développement 1, no. 1 (2010): 11-32.

Bagchi, Barnita, Eckhardt Fuchs, and Kate Rousmaniere, eds. Connecting Histories of Education: Transnational and Cross-cultural Exchanges in (Post) Colonial Education. New York: Berghahn Books, 2014.

Barrington, J. M. "The Permanent Mandates Commission and Educational Policy in Trust Territories." International Review of Education 22, no. 1 (1976): 88-94.

Barthélémy, Pascale. "L’enseignement dans l'Empire colonial français: une vieille histoire?" Histoire de l'éducation, no. 128 (2010): 5-28.

Bates, Julia. "U.S. Empire and the 'Adaptive Education' Model: The Global Production of Race." Sociology of Race and Ethnicity 5, no. l (2019): 41-54.

Bloom, Peter J, Stephan F. Miescher, and Takyiwaa Manuh, eds. Modernization as Spectacle in Africa. Bloomington and Indianapolis: Indiana University Press, 2014.

Bonnecase, Vincent. La pauvreté au Sabel: du savoir colonial à la mesure international. Paris: Karthala, 2011.

Bonneuil, Christophe. "Development as Experiment: Science and State Building in Late Colonial and Postcolonial Africa, 1930-1970." Osiris 15 (2000): $1501-1520$.

Brasseur, Paule. "À propos du congrès de l'évolution culturelle des peuples coloniaux - Paris, 1937." Journal des Africanistes 49, no. 2 (1979): 143-150.

Bude, Udo. "The Adaptation Concept in British Colonial Education." Comparative Education 19, no. 3 (1983): 341-355.

Burton, Eric, ed. "Socialisms in Development." Journal für Entwicklungspolitik XXXIII, no. 3 (2017): 21-48.

Cagé, Julia, and Valeria Rueda. "The Devil Is in the Detail: Christian Missions' Heterogeneous Effects on Development in Sub-Saharan Africa." In The Long Economic and Political Shadow of History, edited by Stelios Michalopoulos and Elias Papaioannou, vol. II: Africa and Asia. London: CEPR Press, 2017. 
Chabbott, Colette. Constructing Education for Development: International Organizations and Education for All. New York: Routledge, 2003.

Cogneau, Denis, Yannick Dupraz, and Sandrine Mesplé-Somps. "African States and Development in Historical Perspective: Colonial Public Finances in British and French West Africa." Paris School of Economics Working Paper (2018).

Cooper, Frederick. "Conditions Analogous to Slavery: Imperialism and Free Labor Ideology in Africa." In Beyond Slavery: Explorations of Race, Labor, and Citizenship in Postemancipation Societies, edited by Frederick Cooper, Thomas C. Holt, and Rebecca J. Scott, 107-149. Chapel Hill: University of North Carolina Press, 2000.

- Décolonisation et travail en Afrique. L'Afrique britannique et française, 1935-1960. Paris: Karthala, 2004.

Cooper, Frederick, and Randall Packard, eds. International Development and the Social Sciences. Berkeley: University of California Press, 1997.

Cullather, Nick. "Development? It's History." Diplomatic History 24, no. 4 (2000): 641-653.

Depaepe, Marc, and António Nóvoa, eds. "The Colonial Experience in Education." Paedagogica Historica 31, supplement 1 (1995).

Dimier, Veronique. The Invention of a European Development Aid Bureaucracy: Recycling Empire. Basingstoke: Palgrave Macmillan, 2014.

- "L'internationalisation du débat colonial: rivalités autour de la Commission Permanente des Mandats." Outre-mers 89, nos. 336-337 (2002): 333-360.

Dores, Hugo Gonçalves. A missão da república: Política, religiãa e o império colonial Português (1910-1926). Lisbon: Edições 70, 2015.

Ekbladh, David. The Great American Mission: Modernization and the Construction of an American World Order, 1914 to the Present. Princeton: Princeton University Press, 2010.

Engerman David C., and Corinna R. Unger. "Introduction: Towards a Global History of Modernization." Diplomatic History 33, no. 3 (2009): 375-385.

Etherington, Norman, ed. Missions and Empire. Oxford: Oxford University Press, 2005.

Fourie, Johan, and Christie Swanepoel. "When Selection Trumps Persistence: The Lasting Effect of Missionary Education in South Africa." Tijdschrift voor Sociale en Economische Geschiedenis 12, no. I (2015): 1-29.

Frankema, Ewout. "Colonial Education and Postcolonial Governance in the Congo and Indonesia." In Colonial Exploitation and Economic Development: The Belgian Congo and the Netherlands Indies Compared, edited by Ewout Frankema, and F. Buelens, 153-177. London: Routledge, 2013. 
. "The Origins of Formal Education in Sub-Saharan Africa: Was British Rule More Benign?" European Review of Economic History 16, no. 4 (2012): 335-355.

Gallego, Francisco A., and Robert D. Woodberry. "Christian Missionaries and Education in Former African Colonies: How Competition Mattered." Journal of African Economics 19, no. 3 (2010): 294-329.

Gamble, Harry. "Peasants of the Empire: Rural Schools and the Colonial Imaginary in 1930s French West Africa." Cabiers d'études africaines 195 (2009): 775-804.

Hailey, Lord. An African Survey: A Study of Problems Arising in Africa South of the Sahara. Oxford: Oxford University Press, 1938.

Hardy, Georges. Une conquête morale. L'enseignement en AOF. Paris: Armand Colin, 1917.

Heldring, Leander, and James Robinson. "Colonialism and Development in Africa." NBER Working Paper, 18566 (2012).

Hodge, Joseph M. "British Colonial Expertise, Post-colonial Careering and the Early History of International Development." Journal of Modern European History 8, no. 1 (2010): 24-46.

- "Writing the History of Development (Part 1: The First Wave)." Humanity 6, no. 3 (2015): 429-463.

- "Writing the History of Development (Part 2: Longer, Deeper, Wider)." Humanity 7, no. 1 (2016): 125-174.

Hodge, Joseph M., Gerald Hodl, and Martina Kopf, eds. Developing Africa: Concepts and Practices in Twentieth-Century Colonialism. Manchester: Manchester University Press, 2014.

Huillery, Elise. "History Matters: the Long-Term Impact of Colonial Public Investments in French West Africa." American Economic Journal: Applied Economics 1, no. 2 (2009): 176-215.

Immerwahr, Daniel. Thinking Small: The United States and the Lure of Community Development. Cambridge: Harvard University Press, 2014.

Institut Colonial International. L'enseignement aux indigènes. Rapports préliminaires, XXIe session, Paris, 5-8 mai 1931. Bruxelles: Établissements généraux d'imprimerie, 1931.

Jedwab, Remi, Felix Meier zu Selhausen, and Alexander Moradi. The Economics of Missionary Expansion: Evidence from Africa and Implications for Development. CSAE Working Paper, Centre for the Study of African Economies, University of Oxford, 2018.

Jerónimo, Miguel Bandeira. The "Civilizing Mission" of Portuguese Colonialism, 1870-1930. Basingstoke: Palgrave Macmillan, 2015.

—. A diplomacia do império. Política e religião na partilha de África (1820-1890). Lisbon: Edições 70, 2012. 
- "A League of Empires: Imperial Political Imagination and Interwar Internationalisms." In Internationalism, Imperialism and the Formation of the Contemporary World, edited by Miguel Bandeira Jerónimo and José Pedro Monteiro, 87-126. London: Palgrave Macmillan, 2017.

—. "Livros Brancos, Almas Negras. Programas e Discursos (1880-1930)." MA diss., New University of Lisbon, 2000.

Jerven, Morten. Poor Numbers: How We Are Misled by African Development Statistics and What to Do About It. Ithaca, NY: Cornell University Press, 2013.

Jones, Phillip W. International Policies for Third World Education: Unesco, Literacy, and Development. London/New York: Routledge, 1988.

Jones, Thomas Jesse. Education in Africa: A Study of West, South, and Equatorial Africa by the African Education Commission. New York: Phelps-Stokes Fund, 1922 .

- Education in East Africa. New York: Phelps-Stokes Fund, 1925.

Kallaway, Peter. "Education, Health, and Social Welfare in the Late Colonial Context: The International Missionary Council and Educational Transition in the Interwar Years with Specific Reference to Colonial Africa." History of Education 38, no. 2 (2009): 217-246.

Kallaway, Peter, and Rebecca Swartz, eds. Empire and Education in Africa: The Shaping of a Comparative Perspective. New York: Peter Lang, 2016.

Katsakioris, Constantin. "Creating a Socialist Intelligentsia: Soviet Educational Aid and Its Impact on Africa (1960-1991)." Cahiers d'études africaines 2, no. 226 (2017): 259-288.

Küster, Sybille. “'Book Learning' Versus 'Adapted Education': The Impact of Phelps-Stokesism on Colonial Education Systems in Central Africa in the Interwar Period." Paedagogica Historica 43, no. l (2007): 79-97.

Labrousse, André. "La France et l'aide à l'éducation aux États africains et malgaxe." Cabiers de l'IIPE, no. 22 (1971): 115-116.

Labrune-Badiane, Céline, Marie-Albane de Suremain, and Pascal Bianchini, eds. L'école en situation postcoloniale. Paris: L'Harmattan, 2012.

Lange, Matthew. Lineages of Despotism and Development: British Colonialism and State Power. Chicago: University of Chicago Press, 2009.

Lembré, Stéphane. "L'enseignement technique et professionnel dans l'Algérie coloniale, du territoire à l'atelier (1866-1958)." Histoire de l'éducation, no. 147 (2017): 91-117.

Lugard, Frederick. The Dual Mandate in British Tropical Africa. Edinburgh: William Blackwood and Sons, 1922.

Madeira, Ana Isabel. "Ler, escrever e orar: Uma análise histórica e comparada dos discursos sobre a educação, o ensino e a escola em Moçambique, 1850-1950." PhD diss., University of Lisbon, 2007. 
. "Portuguese, French and British Discourses on Colonial Education: Church-State Relations, School Expansion and Missionary Competition in Africa, 1890-1930.” Paedagogica Historica 41, nos. 1-2 (2005): 31-60.

Malinowski, Stephan, Andreas Eckert, and Corinna Unger, eds. "Modernizing Missions: Approaches to the 'Developing' the Non-Western World After 1945." Journal of Modern European History 8, no. 1 (2010): 35-63.

Manela, Erez, and Stephen Macekura, eds. The Development Century: A Global History. Cambridge: Cambridge University Press, 2018.

Manière, Laurent. "La politique française pour l'adaptation de l'enseignement en Afrique après les indépendances (1958-1964)." Histoire de l'éducation, no. 12 (2010): 163-190.

Marshall, Dominique. “Children's Rights in Imperial Political Cultures: Missionary and Humanitarian Contributions to the Conference on the African Child of 1931." The International Journal of Children's Rights 12, no. 3 (2004): 273-318.

Matasci, Damiano. "Assessing Needs, Fostering Development: UNESCO, Illiteracy and the Global Politics of Education (1945-1960)." Comparative Education 53, no. 1 (2017): 35-53.

_. "Une 'UNESCO africaine'? Le ministère de la France d'Outre-mer, la coopération éducative intercoloniale et la défense de l'Empire, 1947-1957." Monde(s), no. 13 (2018): 195-214.

Maul, Daniel. Human Rights, Development and Decolonization: The International Labour Organization, 1940-1970. London: Palgrave Macmillan, 2012.

McLeod, Julie, and Fiona Paisley. "The Modernization of Colonialism and the Educability of the 'Native': Transpacific Knowledge Networks and Education in the Interwar Years." History of Education Quarterly 56, no. 3 (2016): 473-502.

Mesli, Samy. "French Coopération in the Field of Education (1960-1980): A Story of Disillusionment." In Francophone Africa at Fifty, edited by Tony Chafer and Alexander Keese, 120-134. Manchester: Manchester University Press, 2013.

Meyer, John, et al. "The World Educational Revolution, 1950-1970." Sociology of Education 50 (1977): 242-258.

Michalopoulos, Stelios, and Elias Papaioannou, eds. The Long Economic and Political Shadow of History, vol. II: Africa and Asia. London: CEPR Press, 2017.

Naylor, Ed, ed. France's Modernising Mission: Citizenship, Welfare and the Ends of Empire. Basingstoke: Palgrave Macmillan, 2018.

Nunn, Nathan. "Gender and Missionary Influence in Colonial Africa." In Africa's Development in Historical Perspective, edited by Emmanuel Akyeampong, Robert H. Bates, Nathan Nunn, and James A. Robinson, 489-512. New York: Cambridge University Press, 2014. 
. "The Importance of History for Economic Development." Annual Review of Economics 1, no. 1 (2009): 65-92.

Paulo, João Carlos. "What Does Indigenous Education Mean? Portuguese Colonial Thought and the Construction of Ethnicity and Education." Paedagogica Historica 37, no. 1 (2001): 231-250.

Pearson, Jessica Lynne. The Colonial Politics of Global Health: France and the United Nations in Postwar Africa. Harvard: Harvard University Press, 2018.

Pedersen, Susan. The Guardians: The League of Nations and the Crisis of Empire. Oxford: Oxford University Press, 2015.

Porter, Andrew. Religion Versus Empire? British Protestant Missionaries and Overseas Expansion, 1700-1914. Manchester: Manchester University Press, 2004.

Sarraut, Albert. La mise en valeur des colonies françaises. Paris: Payot et Cie, 1923.

Seghers, Maud. "Phelps-Stokes in Congo: Transferring Educational Policy Discourse to Govern Metropole and Colony." Paedagogica Historica 40, no. 4 (2004): 455-477.

Singaravelou, Pierre. "Les stratégies d'internationalisation de la question coloniale et la construction transnationale d'une science de la colonisation à la fin du XIXe siècle." Monde(s) 1, no. I (2012): 135-157.

Smith, Edwin W. The Christian Mission in Africa, a Study Based on the Work of the International Conference at Le Zoute, Belgium, September 14th to 21st, 1926. London: International Missionary Council, 1926.

Stanley, Brian. The Bible and the Flag: Protestant Missions and British Imperialism in the Nineteenth and Twentieth Centuries. Leicester: Appollos, 1990.

Staples, Amy L. S. The Birth of Development: How the World Bank, Food and Agriculture Organization, and World Health Organization changed the World, 1945-1965. Kent: Kent State University Press, 2006.

Steiner-Khamsi, Gita, and Hubert Quist. "The Politics of Educational Borrowing: Reopening the Case of Achimota in British Ghana." Comparative Education Review 44, no. 3 (2000): 272-299.

Thomas, Martin, Bob Moore, and Larry Butler. Crises of Empire. London: Hodder Education, 2008.

Tournès, Ludovic, and Giles Scott-Smith, eds. Global Exchanges: Scholarship Programs and Transnational Circulations in the Modern World. New York: Berghahn Books, 2017.

UNESCO. Fundamental Education: Common Ground for All Peoples: Report of a Special Committee to the Preparatory Commission of Unesco. Paris: UNESCO, 1946.

Unger, Corinna R., Marc Frey, and Sonke Kunkel, eds. "Histories of Development and Modernization: Findings, Reflections, Future Research." H-Soz-Kult, 9 December 2010. http://hsozkult.geschichte.hu-berlin.de/ forum/2010-12-001. 

2018.

International Organizations and Development (1945-1990).
Basingstoke: Palgrave Macmillan, 2014. Elites." In Elites and Decolonization in the Twentieth Century, edited by Jost Dülffer and Marc Frey, 241-261. Basingstoke: Palgrave Macmillan, 2011.

Verna, Chantalle F. "Haiti, the Rockfeller Foundation, and UNESCO's Pilot Project in Fundamental Education, 1948-1953." Diplomatic History 40, no. 2 (2016): 269-295.

Watras, Joseph. "UNESCO's Programme of Fundamental Education, 1946-1959." History of Education 39, no. 2 (2010): 219-237.

Westad, Odd Arne. La guerre froide globale. Paris: Payot, 2005.

White, Owen, and J. P. Daughton, eds. In God's Empire: French Missionaries and the Modern World. Oxford: Oxford University Press, 2012.

Whitehead, Clive. "The Historiography of British Imperial Education Policy, Part II: Africa and the Rest of the Colonial Empire." History of Education 34, no. 4 (2005): 441-454.

Wrong, Margaret. "Mass Education in Africa." African Affairs 43, no. 172 (1944): 105-111.

Zimmerman, Andrew. Alabama in Africa: Booker T. Washington, the German Empire, and the Globalization of the New South. Princeton: Princeton University Press, 2010.

Open Access This chapter is licensed under the terms of the Creative Commons Attribution 4.0 International License (http://creativecommons.org/licenses/ by $/ 4.0 /$ ), which permits use, sharing, adaptation, distribution and reproduction in any medium or format, as long as you give appropriate credit to the original author(s) and the source, provide a link to the Creative Commons license and indicate if changes were made.

The images or other third party material in this chapter are included in the chapter's Creative Commons license, unless indicated otherwise in a credit line to the material. If material is not included in the chapter's Creative Commons license and your intended use is not permitted by statutory regulation or exceeds the permitted use, you will need to obtain permission directly from the copyright holder.

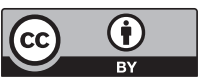

